\title{
Obituary
}

Editor: Henry R. Rollin

\section{Patrick Joseph Gerard QuinN, formerly Physician Superintendent, Clifton Hospital, York}

Dr P. J. G. Quinn - Jerry to his friends - was born in Northern Ireland on 29 April 1914. He was educated at the Christian Brothers School in Dublin and studied medicine at the Royal College of Surgeons of Ireland. He qualified LRCP in 1936 having been awarded the MacNaughton Jones Gold Medal in Obstetrics and Gynaecology and the Mercer Gold Medal in Medicine and Surgery.

He initially entered general practice, but in 1940 he was commissioned in the RAMC and served as RMO to the 4th Battalion, the Dorset Regiment. At the end of the war he was posted to India where, in Dacca, he married his wife, Maureen, in April 1945.

After the war he returned for a while to general practice before joining the Prison Medical Service in 1949 where he served for some four years. He moved into psychiatry as Senior Hospital Medical Officer at St George's Hospital, Morpeth in 1953. In September 1956 he was appointed Consultant Psychiatrist at St Nicholas Hospital, Gosforth where he remained until April of 1965, being Deputy Physician Superintendent in the latter five years.

He attained the Membership of the Royal College of Physicians of Ireland in 1948 and was elected a Fellow of that body in 1974. He was elected a founder Fellow of the Royal College of Psychiatrists in 1971.

In 1965 Jerry was appointed Physician Superintendent at Clifton Hospital, York where he remained until his retirement in April 1979. He maintained an interest in forensic psychiatry as visiting psychiatrist to Benton Grange Approved School, and as one of a panel of Home Office Visiting Psychiatrists who examined prisoners charged with murder.

He was for some years Chairman of the York and District Mental Health Association and served as a member of the Mental Health Review Tribunal both in Newcastle and in the Leeds Region. A keen practising Catholic, he was Secretary and at one time Master of the Newcastle upon Tyne branch of the Catholic Doctors Guild.

Jerry Quinn led the Mental Hospital Team in York in the days when his hospital was a centre of excellence for the whole of North Yorkshire, and where the true community care which such an institution could provide still existed. It was a caring place where all who were involved felt the esprit de corps which such a real community engendered. There remained an overriding sense of loyalty between staff of all disciplines and if anyone was in trouble, it was always possible to turn to Jerry for support, advice and a sensible but kindly consideration of the problem.

When I first joined the staff Jerry led a team of professionals all of whom could count upon each other and who shared the common purpose of caring for the mentally disabled when often there was no other support. After his retirement, Jerry and Maureen returned to County Wicklow and to the Irish Republic to enjoy their last years together. The news of his death will come as a sad blow to many who knew him.

MTH

\section{The deaths of the following have also been reported:}

Donald Alexander Sangster Blair, formerly Consultant Psychiatrist; Sandy Lane Farm, Dunwich, Saxmundham, Suffolk.

George StePhen Cadogan, formerly Consultant Psychiatrist, Winwick Hospital, Cheshire.

Robert Brian Dobson, Consultant Psychiatrist, 57 Bath Road, Reading, Berkshire.

LiselotTE FrankL, Psychoanalyst, Hampstead Child Therapy Clinic, 21 Maresfield Gardens, London NW3.

DOREEN MARY HoBson, formerly Community Medical Specialist, Croydon AHA.

Olive BallanCe InMan, formerly Psychotherapist, Graylingwell Hospital, Chichester, Sussex.

MaRCUS DECLAN LYNCH, formerly Consultant Psychiatrist, Turner Village Hospital, Colchester, Essex.

Gabriel Nolan, Consultant Psychiatrist, St Loman's Hospital, Lucan, Co. Dublin.

JAMES JoSEPH O'ReILLY, formerly Medical Superintendent, 22 Crescent Walk, West Parley, Wimborne, Dorset.

Douglas Eaton Wallace, formerly Consultant Psychiatrist, Rainhill Hospital, Merseyside.

Nicholas N. Dracoulides, Psychoanalyst, President, Psycho-Biological Association, Athens, Greece. 